\title{
PENERAPAN STRATEGI PEMBELAJARAN AKTIF EACH ONE TEACH ONE DENGAN MEDIA PUZZLE MAGNET UNTUK MENINGKATKAN HASIL BELAJAR MATEMATIKA MATERI POKOK BANGUN RUANG SISI DATAR DI KELAS VIII-E
}

\author{
${ }^{1}$ Apit Mardjiatno \\ ${ }^{1}$ SMP Negeri 1 Situbondo \\ Email: $\underline{\text { m apit@gmail.com }}$
}

Received: July 25, 2021 Revised: July 30, $2021 \quad$ Accepted: Augst 9, 2021

\begin{abstract}
ABSTRAK
Strategi pembelajaran Matematika yang ada, strategi pembelajaran Each One Teach One sangat potensial untuk diterapkan dalam upaya peningkatan hasil belajar siswa. Strategi pembelajaran Each One Teach One dikembangkan dari pemikiran nilai-nilai demokrasi, belajar efektif, perilaku kerja sama dan menghargai keanekaragaman di masyarakat. Dalam pembelajaran, guru harus dapat menciptakan lingkungan belajar sebagai suatu sistem sosial yang memiliki proses demokrasi dan proses ilmiah. strategi pembelajaran Each One Teach One merupakan suatu strategi pembelajaran yang mengaktifkan siswa dengan siswa mampu menjelaskan jawabannya. Dengan adanya Strategi pembelajaran aktif Each One Teach One dengan Media puzzle magnet diharapkan dapat meningkatkan aktivitas dan hasil belajar. Desain penelitian menggunakan PTK. Teknik pengumpulan data berupa observasi, wawancara, tes dan dokumentasi. Berdasarkan hasil analisa data yang telah dikemukakan di bab IV dapat diuraikan sebagai berikut: penerapan strategi pembelajaran aktif each one teach one dengan media puzzle magnet dapat meningkatkan hasil belajar dari $69 \%$ siklus I menjadi $94 \%$ siklus II mata pelajaran matematika di kelas VIII-E di SMP Negeri 1 Situbondo Semester genap tahun pelajaran 2018/2019.
\end{abstract}

Kata Kunci : aktif Each One Teach One, Media puzzle magnet, Hasil Belajar

\section{PENDAHULUAN}

. Data di SMP Negeri 1 Situbondo menunjukkan nilai rata-rata mata pelajaran yang kurang maksimal, belum seperti yang diharapkan dimana nilai rata-ratanya adalah 68 (dengan Kriteria Ketuntasan Minimal 70,00). Ketuntasan belajar secara klasikal hanya mencapai $40 \%$.

Berdasarkan uraian di atas, strategi pembelajaran Each One Teach One tidak hanya meningkatkan prestasi dan pemahaman siswa tetapi juga meningkatkan sifat berpikir kreatif, kepemimpinan, sikap positif terhadap materi pelajaran, dan rasa saling menghargai. Kelebihan dalam pembelajaran ini sangat diperlukan dalam pembelajaran Matematika terutama dalam pengembangan kemampuan berpikir kreatif. 


\section{METODE PENELITIAN}

Dalam penelitian ini rancangan penelitian yang digunakan yaitu tindakan kelas. Menurut Maleong (2012:3) penelitian kualitatif adalah tradisi tertentu dalam matematika yang secara fundamental bergantung pada pengalaman manusia dalam kawasannya sendiri dan berhubungan dengan orang tersebut dalam bahasanya dan dalam perhatiannya.

Desain penelitian yang dipakai dalam penelitian ini adalah model skema spiral dari Kemmis Taggar (dalam Arikunto, 2015:27) dengan menggunakan empat fase yaitu: perencanaan, tindakan, observasi dan refleksi. Keempat fase tersebut merupakan suatu siklus untuk melaksanakan penelitian tindakan kelas ditunjukkan dengan bagan berikut:

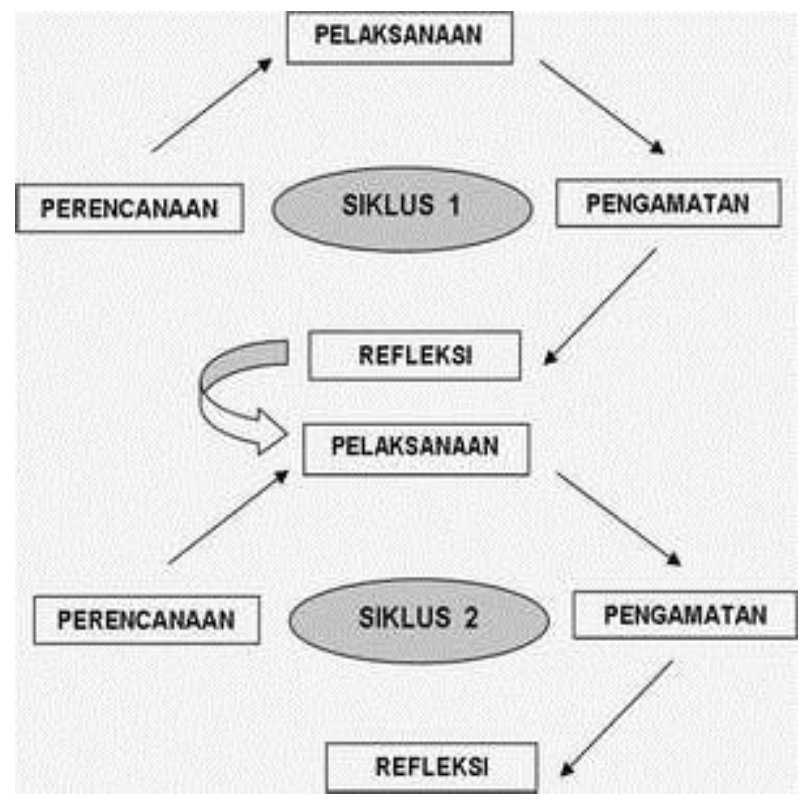

(Kemmis Taggar, dalam Arikunto, 2015:27)

Dalam penelitian tindakan kelas pelaksanaan siklus tidak dibatasi, akan tetapi harus disesuaikan dengan kondisi yang dihadapi peneliti dalam melaksanakan penelitian tindakan kelas. Peneliti melaksanakan dua siklus untuk menerapkan strategi pembelajaran aktif each one teach one dalam upaya meningkatkan aktivitas dan hasil belajar siswa. Siklus dalam pelaksanaan ini terdiri dari empat tahapan yaitu rencana, tindakan, observasi dan refleksi. 


\section{Hasil Penelitian Prasiklus}

Pada prasiklus kegiatan pembelajaran belum berhasil, karena belum memiliki tolok ukur keberhasilan yaitu secara klasikal yang mendapat nilai 70 minimal 85\%. Hal ini dibuktikan dengan hasil ulangan siswa pada prasiklus yang tuntas hanya 19 orang sedangkan sisanya 16 siswa belum tuntas. Hal ini disebabkan masih banyak siswa yang kurang aktif dalam mengikuti kegiatan belajar mengajar, siswa tidak menguasai materi prasyarat yaitu Menentukan luas permukaan dan volume kubus, balok, prisma dan limas. Dengan demikian peneliti perlu melakukan tindakan selanjutnya untuk meningkatkan kemampuan siswa dalam menyebutkan dan menentukan luas permukaan dan volume kubus, balok, prisma dan limas.

Hasil observasi akan dijadikan pedoman bagi peneliti untuk melaksanakan penelitian dengan penerapan pembelajaran Strategi pembelajaran aktif each one teach one dengan media puzzle magnet. Peneliti menemukan masih banyak siswa yang kurang mampu mempresentasikan hasil belajar depan kelas dan siswa masih kurang mampu pula menganalisa dan mengevaluasi proses pemecahan masalah. Dalam penelitian ini peneliti menerapkan pembelajaran yang mampu memecahkan masalah-masalah utama dalam belajar yaitu pembelajaran Strategi pembelajaran aktif each one teach one dengan media puzzle magnet.

Sebelum mengadakan pembelajaran Strategi pembelajaran aktif each one teach one dengan media puzzle magnet peneliti mengadakan wawancara dengan guru mata pelajaran Matematika yang menyatakan bahwa kelas VIII-E merupakan kelas yang nilai rata-rata ulangan harian terendah. Sedangkan rata-rata nilai ulangan sebelum tindakan 58,06 dengan ketuntasan klasikal mencapai 54\% atau 19 siswa yang tuntas dengan menggunakan metode ceramah yang guru terapkan di kelas sehingga peneliti ingin menerapkan mengadakan pembelajaran Strategi pembelajaran aktif each one teach one dengan media puzzle magnet yang diharapkan dapat meningkatkan hasil belajar siswa dengan siswa dibentuk guru (siswa) yang akan menjelaskan di depan kelas.

\section{Pelaksanaan Siklus 1}

Hal-hal yang dilakukan selama pelaksanaan siklus 1, adalah sebagai berikut:

\section{Perencanaan}

Kegiatan yang dilakukan pada tahap perencanaan ini adalah melaksanakan kegiatan sesuai dengan desain yang telah dibuat sebelumnya (seperti yang dijelaskan pada Bab III). Pada tahap ini semua persiapan yang telah dilakukan, setelah dilakukan diskusi antara guru, peneliti dan observer, baik yang berkaitan dengan persiapan mengajar (menyusun Silabus, RPP, Soal dan kunci jawaban) maupun persiapan 
lainnya meliputi membuat panduan observasi, mengajukan siswa yang akan menjadi calon tutor.

\section{Pelaksanaan Tindakan}

Pertemuan Pertama

Pelaksanaan pertemuan pertama ini sudah mulai menggunakan Strategi pembelajaran aktif each one teach one dengan media puzzle magnet pada sub pokok bahasan Menentukan luas permukaan dan volume kubus, balok, prisma dan limas.

Adapun langkah-langkah yang diambil oleh guru dengan dibantu oleh peneliti dalam menerapkan pembelajaran Strategi pembelajaran aktif each one teach one dengan media puzzle magnet pada pertemuan pertama adalah sebagai berikut:

Guru meminta siswa bergerak berkeliling (dapat searah jarum jam atau terserah guru) dan saling berbagi tentang pernyataan itu dengan siswa yang lain. Mereka diperbolehkan menjelaskan pengetahuannya tentang pernyataan itu dengan siswa lain sebanyak mungkin. Guru meminta siswa dapat bekerja dalam kelompok kecil-kecil untuk menggolongkan informasi yang mereka terima selama proses pembelajaran merupakan kegiatan mengumpulkan informasi.

Guru memberikan motivasi siswa untuk mempertajam penjelasannya dengan memberikan contoh-contoh yang relevan, atau dengan mengaitkan pernyataan tersebut dengan pernyataan siswa yang lain. Guru membimbing siswa menggunakan data untuk menghitung luas jaring-jaring kotak dan meminta siswa untuk menyampaikan hasilnya. Guru memberikan model kotak dengan ukuran yang berbeda-beda kemudian siswa diminta menentukan luas permukaannya melalui pembuatan jaring-jaring dan menggunakan model matematika yang telah ditemukan.

Guru membimbing siswa dalam kelompok untuk menyimpulkan bagaimana cara menentukan luas permukaan balok maupun kubus dan merumuskannya. Bahwa : Luas permukaan balok $=2(\mathrm{pl}+\mathrm{pt}+\mathrm{lt})$ dan Luas permukaan kubus $=6(\mathrm{sxs})=6 \mathrm{~s}^{2}$. Guru meminta siswa sebagai wakil siswa kelompok (Mengkomunikasikan ). Temuan utama dapat dituliskan di papan tulis

Kegiatan penutup yaitu Guru memberikan tugas pelajaran rumah, pemberian tugas dimaksudkan untuk menyeimbangkan pengetahuan (mandiri).

Pelaksanaan pertemuan pertama siswa yang ditunjuk menjadi tutor. Siswa masih merasa agak kaku dengan lingkungan kelompok yang kurang kondusif. Namun pada kesempatan siswa untuk berfikir kreatif pada saat mengerjakan soal-soal. Siswa saling menukar jawaban untuk dikoreksi dengan bimbingan guru, hal ini dilakukan untuk meningkatkan interaksi sosial. 


\section{Pertemuan Kedua}

Pelaksanaan pertemuan kedua ini mengacu pada kompetensi dasar yaitu Menentukan luas permukaan dan volume kubus, balok, prisma dan limas. Kegiatan pendahuluan yaitu Guru memberikan apersepsi kepada siswa sesuai dengan materi yang akan dibahas (ingin tahu).

Kegiatan Inti yaitu guru memberikan selembar kertas yang berisi sejumlah pernyataan tentang fakta atau statistik tertentu dibagikan kepada setiap siswa, sepantasnya setiap siswa menerima pernyataan atau fakta yang berbeda. (Mengamati) Guru membimbing siswa untuk mengidentifikasi masalah. Siswa diminta untuk menyampaikan hasil identifikasinya.

Guru menampung apa yang disampaikan siswa kemudian menegaskan masalah yang sebenarnya. "Dapatkah kalian menemukan luas permukaan sebuah kubus?." "Dapatkah kalian menemukan luas permukaan sebuah balok?."

Siswa diberi soal berkaitan dengan luas permukaan kubus dan balok. Siswa secara berkelompok diminta mendiskusikan dengan anggota kelompok lainnya. Guru membimbing siswa dalam kelompok untuk mengumpulkan informasi yang diperoleh dari percobaan membuka kedua kotak tersebut sehingga membentuk jaring-jaring.

Guru meminta siswa secara mandiri membaca pernyataan tertulis itu untuk paham dan yakin tentang apa maknanya kegiatan ini mencerminkan kegiatan mengumpulkan informasi) Siswa diminta untuk mencari informasi dan siswa memperoleh pemahaman tentang jaring-jaring balok maupun kubus. Guru meminta siswa bergerak berkeliling (dapat searah jarum jam atau terserah guru) dan saling berbagi tentang pernyataan itu dengan siswa yang lain. Mereka diperbolehkan menjelaskan pengetahuannya tentang pernyataan itu dengan siswa lain sebanyak mungkin.

Guru meminta siswa dapat bekerja dalam kelompok kecil-kecil untuk menggolongkan informasi yang mereka terima selama proses pembelajaran. (Mengumpulkan informasi). Guru memberikan motivasi siswa untuk mempertajam penjelasannya dengan memberikan contoh-contoh yang relevan, atau dengan mengaitkan pernyataan tersebut dengan pernyataan siswa yang lain.

Guru membimbing siswa menggunakan data untuk menghitung luas jaring-jaring kotak dan meminta siswa untuk menyampaikan hasilnya. Guru memberikan model kotak dengan ukuran yang berbeda-beda kemudian siswa diminta menentukan luas permukaannya melalui pembuatan jaring-jaring dan menggunakan model matematika yang telah ditemukan. Guru membimbing siswa dalam kelompok untuk menyimpulkan bagaimana cara menentukan luas permukaan balok maupun kubus dan merumuskannya. Bahwa : Luas permukaan balok $=2(\mathrm{pl}+\mathrm{pt}+\mathrm{lt})$ dan Luas permukaan kubus $=6(\mathrm{sxs})=$ 
$6 s^{2}$. Kegiatan guru meminta siswa sebagai wakil siswa kelompok (Mengkomunikasikan ). Temuan utama dapat dituliskan di papan tulis

Kegiatan penutup yaitu Guru memberikan tugas pelajaran rumah, pemberian tugas dimaksudkan untuk menyeimbangkan pengetahuan (mandiri).

\section{Observasi Siswa}

Siswa ini harus diberi motivasi agar lebih bersemangat dalam proses belajar mengajar, antara lain diberi pertanyaan yang berhubungan dengan materi yang disampaikan. Bila jawaban benar, guru supaya memberi penguatan agar siswa senang. Guru harus memberi motivasi tentang manfaat menguasai pokok bahasan ini sangat penting, karena dapat digunakan untuk menyelesaikan masalah-masalah dalam kehidupan sehari-hari.

Dengan melihat tabel pengamatan oleh guru lain, dapat dijelaskan bahwa dalam siklus I kemampuan guru dalam mengulas materi sudah baik, tetapi bimbingan guru kurang merata sehingga ada beberapa siswa yang tidak bisa mengerjakan soal dengan benar. Adapun siswa yang ditunjuk untuk menyajikan materi, menguasai materi akan tetapi dalam penyampaiannya kurang di pahami siswa lainnya karena suara yang kurang keras dan tulisan yang terlalu kecil sehingga ada beberapa siswa yang bermain (ngobrol) sendiri.

Pada siklus 1 mencapai ketuntasan belajar siswa 69\% atau 24 siswa yang mampu mendapat nilai di atas 70 . Nilai tersebut masih dibawah KKM yang ditetapkan oleh sekolah yaitu secara klasikal $85 \%$.

Kesimpulannya pada siklus I kegiatan pembelajaran belum berhasil, karena belum memiliki tolok ukur keberhasilan yaitu secara klasikal yang mendapat nilai 70 minimal $85 \%$. Hal ini disebabkan masih banyak siswa yang kurang aktif dalam mengikuti kegiatan belajar mengajar, siswa tidak menguasai materi prasyarat yaitu Menentukan luas permukaan dan volume kubus, balok, prisma dan limas. Dengan demikian peneliti perlu melakukan tindakan selanjutnya untuk meningkatkan kemampuan siswa dalam menyebutkan dan menentukan luas permukaan dan volume kubus, balok, prisma dan limas.

Berdasarkan hasil observasi yang teman sejawat lakukan terhadap aktivitas peneliti/guru selama pelaksanaan tindakan pada siklus I, dalam menerapkan Strategi pembelajaran aktif each one teach one dengan media puzzle magnet bahwa guru sudah dapat menerapkan Strategi pembelajaran aktif each one teach one dengan media puzzle magnet, sesuai dengan prosedur dan langkah-langkahnya. Namun pada saat proses pengelompokan dan pengaturan kelompok siswa masih ramai dan terlihat kurang teratur, sehingga banyak menyita waktu pelajaran. Guru juga belum maksimal dalam 
memberikan pengakuan atau penghargaan terhadap siswa yang telah melakukan aktivitas belajarnya dengan baik.

\section{Refleksi}

Hasil belajar pada siklus 1 mencapai 69\% atau 24 siswa yang tuntas Rendahnya hasil belajar siswa disebabkan oleh siswa masih menyesuaikan diri dengan kelompoknya sehingga perlu adanya peningkatan pada hasil belajar dengan cara guru hanya sebagai fasilitator dan memberikan kesempatan siswa untuk memilih tutor dalam kelompok yang menurut mereka baik, maka perlu adanya perbaikan pada siklus ke II untuk perbaikan pada hasil dan hasil belajar siswa dengan cara pada siklus I guru yang menentukan tutor sebaya dalam kelompok namun pada siklus II, guru memberikan kesempatan kepada siswa untuk memilih dan menentukan tutor sebaya yang dianggap bagi kelompok tersebut mampu untuk membimbing anggotanya.

Saat guru mengadakan permainan dengan meminta siswa mencocokkan soal dengan jawabannya masih kaku. Namun perlu diadakan siklus II dikarenakan hasil belajar siswa kurang mencapai KKM yaitu $85 \%$ hal ini disebabkan oleh siswa kurang mampu untuk mengerjakan soal dengan benar.

Peningkatan yang pesat pada prosentase hasil observasi tingkah laku siswa dalam keterlibatan siswa dalam belajar mengajar, antara lain meliputi siswa tidak takut atau berani dalam mengemukakan pendapat dalam belajar kelompok pada analisis observasi I di siklus I, sedangkan hasil belajar pada siklus 1 rata-rata nilai ulangan siswa kelas VIII-E yaitu 69,86. Ketuntasan secara klasikal mencapai 69\% atau 24 siswa yang tuntas dan siswa yang belum tuntas 24 siswa atau $69 \%$.

\section{Pelaksanaan Siklus II}

\section{Perencanaan}

Berdasarkan hasil belajar pada siklus 1 bahwa siswa yang daya serapnya tinggi belum mampu dikatakan guru atau tutor karena siswa yang daya serapnya tinggi tidak mampu membimbing siswa lain hanya siswa yang sedang daya serapnya mampu memberikan motivasi kepada siswa lain. Tutor tersebut merupakan pilihan dari guru sehingga perlu adanya kesempatan kepada siswa untuk memilih tutor atau guru dalam kelompok. Kegiatan yang dilakukan pada tahap perencanaan ini adalah melaksanakan kegiatan sesuai dengan desain yang telah dibuat sebelumnya (seperti yang dijelaskan pada siklus I), pada tahap ini semua persiapan telah dilakukan setelah dilakukan diskusi antara guru, peneliti dan observer, baik yang berkaitan dengan persiapan mengajar (menyusun rencana pembelajaran pada Pokok Bahasan yang akan 
dibahas, gambar dan perlengkapan dalam Pokok Bahasan yang akan dibahas, soal sebagai bahan diskusi baik diluar kelas maupun di dalam kelas dan kunci jawaban serta mempersiapkan deskriptif tugas tim peneliti.

\section{Pelaksanaan Tindakan}

Adapun kegiatan belajar mengajar dapat diuraikan sebagai berikut: Kegiatan Guru membimbing siswa untuk mengidentifikasi masalah. Siswa diminta untuk menyampaikan hasil identifikasinya. Guru menampung apa yang disampaikan siswa kemudian menegaskan masalah yang sebenarnya. "Dapatkah kalian menemukan luas permukaan sebuah kubus?." "Dapatkah kalian menemukan luas permukaan sebuah balok?.” Siswa diberi soal berkaitan dengan luas permukaan kubus dan balok. Siswa secara berkelompok diminta mendiskusikan dengan anggota kelompoknya.

Kegiatan guru membimbing siswa dalam kelompok untuk mengumpulkan Guru meminta siswa bergerak berkeliling (dapat searah jarum jam atau terserah guru) dan saling berbagi tentang pernyataan itu dengan siswa yang lain. Mereka diperbolehkan menjelaskan pengetahuannya tentang pernyataan itu dengan siswa lain sebanyak mungkin. Guru meminta siswa dapat bekerja dalam kelompok kecil-kecil untuk menggolongkan informasi yang mereka terima selama proses pembelajaran. (Mengumpulkan informasi). Guru memberikan model kotak dengan ukuran yang berbeda-beda kemudian siswa diminta menentukan luas permukaannya melalui pembuatan jaring-jaring dan menggunakan model matematika yang telah ditemukan. Guru membimbing siswa dalam kelompok untuk menyimpulkan bagaimana cara menentukan luas permukaan balok maupun kubus dan merumuskannya. Bahwa : Luas permukaan balok $=2(\mathrm{pl}+\mathrm{pt}+\mathrm{lt})$. Luas permukaan kubus $=6(\mathrm{sxs})=6 \mathrm{~s}^{2}$. Guru meminta siswa sebagai wakil siswa kelompok merupakan kegiatan mengkomunikasikan. Temuan utama dapat dituliskan di papan tulis.

Kegiatan penutup yaitu guru memberikan tugas pelajaran rumah, pemberian tugas dimaksudkan untuk menyeimbangkan pengetahuan (mandiri).

Pertemuan Keempat

Adapun kegiatan belajar mengajar dapat diuraikan sebagai berikut: kegiatan pendahuluan yaitu guru memberikan apersepsi kepada siswa sesuai dengan materi yang akan dibahas (ingin tahu). Kegiatan Inti yaitu Guru memberikan selembar kertas yang berisi sejumlah pernyataan tentang fakta atau statistik tertentu dibagikan kepada setiap siswa, sepantasnya setiap siswa menerima pernyataan atau fakta yang berbeda merupakan kegiatan mengamati. Guru membimbing siswa untuk mengidentifikasi masalah. Siswa diminta untuk menyampaikan hasil identifikasinya. Guru menampung apa yang disampaikan siswa kemudian menegaskan masalah yang sebenarnya. 
Dapatkah kalian menemukan luas permukaan sebuah kubus?." Pertanyaan kedua "Dapatkah kalian menemukan luas permukaan sebuah balok?. Siswa diberi soal berkaitan dengan luas permukaan kubus dan balok." Siswa secara berkelompok diminta mendiskusikan soal guru membimbing siswa dalam kelompok untuk mengumpulkan informasi yang diperoleh dari percobaan membuka kedua kotak tersebut sehingga membentuk jaring-jaring.

Guru meminta siswa secara mandiri membaca pernyataan tertulis itu untuk paham dan yakin tentang apa maknanya kegiatan mengumpulkan informasi. Siswa diminta untuk mencari informasi dan memperoleh pemahaman tentang jaring-jaring balok maupun kubus. Guru meminta siswa bergerak berkeliling (dapat searah jarum jam atau terserah guru) dan saling berbagi tentang pernyataan itu dengan siswa yang lain. Mereka diperbolehkan menjelaskan pengetahuannya tentang pernyataan itu dengan siswa lain sebanyak mungkin. Guru meminta siswa dapat bekerja dalam kelompok kecil-kecil untuk menggolongkan informasi yang mereka terima selama proses pembelajaran kegiatan mengumpulkan informasi. Guru memberikan model kotak dengan ukuran yang berbeda-beda kemudian siswa diminta menentukan luas permukaannya melalui pembuatan jaring-jaring dan menggunakan model matematika yang telah ditemukan. Guru membimbing siswa dalam kelompok untuk menyimpulkan bagaimana cara menentukan luas permukaan balok maupun kubus dan merumuskannya. Bahwa rumus dari luas permukaan balok $=2(\mathrm{pl}+\mathrm{pt}+\mathrm{lt})$. Luas permukaan kubus $=6(\mathrm{sxs})=6 \mathrm{~s}^{2}$. Guru meminta siswa sebagai wakil siswa kelompok kegiatan mengkomunikasikan. Temuan utama dapat dituliskan di papan tulis.

Kegiatan penutup (10') yaitu Guru memberikan tugas pelajaran rumah, pemberian tugas dimaksudkan untuk menyeimbangkan pengetahuan (mandiri).

\section{Observasi}

Siswa ini harus diberi motivasi agar lebih bersemangat dalam proses belajar mengajar, antara lain diberi pertanyaan yang berhubungan dengan materi yang disampaikan. Bila jawaban benar, guru supaya memberi penguatan agar siswa senang. Guru harus memberi motivasi tentang manfaat menguasai pokok bahasan ini sangat penting, karena dapat digunakan untuk menyelesaikan masalah-masalah dalam kehidupan sehari-hari.

Dengan melihat tabel pengamatan oleh guru lain, dapat dijelaskan bahwa dalam siklus II kemampuan guru dalam mengulas materi sudah baik, tetapi bimbingan guru kurang merata sehingga ada beberapa siswa yang mampu mengerjakan soal dengan benar. 


\section{Analisis Ulangan}

Pada siklus 2 mencapai ketuntasan belajar siswa 94\% atau 33 siswa yang mampu mendapat nilai di atas 70. Nilai tersebut masih dibawah KKM yang ditetapkan oleh sekolah yaitu secara klasikal $85 \%$.

Kesimpulannya pada siklus I kegiatan pembelajaran belum berhasil, karena belum memiliki tolok ukur keberhasilan yaitu secara klasikal yang mendapat nilai 70 minimal 85\%. Hal ini disebabkan masih banyak siswa yang kurang aktif dalam mengikuti kegiatan belajar mengajar, siswa tidak menguasai materi prasyarat yaitu Menentukan luas permukaan dan volume kubus, balok, prisma dan limas. Dengan demikian peneliti perlu melakukan tindakan selanjutnya untuk meningkatkan kemampuan siswa dalam menyebutkan dan menentukan luas permukaan dan volume kubus, balok, prisma dan limas.

\section{Observasi Aktivitas Guru}

Pada siklus II siswa yang kurang aktif sudah berkurang dibanding siklus II. Dari hasil belajar siswa juga mengalami peningkatan, terbukti siswa yang tidak tuntas belajar ada 2 siswa (6\%). Hal ini sulit di hilangkan sebab faktor internal anak itu sendiri, namun peneliti memberikan bimbingan khusus pada anak tersebut. Sedang yang tuntas belajar ada 33 siswa (94\%) dengan nilai rata-rata 87,29 sedang daya serapnya $94 \%$ berarti mengalami peningkatan kemampuan siswa dalam menyebutkan Menentukan luas permukaan dan volume kubus, balok, prisma dan limas, sedang pengamatan kegiatan belajar mengajar oleh guru lain, kegiatan peneliti sudah ada peningkatan dibanding siklus II, karena perhatian guru lebih merata dan siswa yang pasif diberi soal untuk diselesaikannya dan dibimbing oleh guru, sehingga siswa menjadi aktif.

Dengan model pembelajaran berbalik siswa semakin aktif dan terampil dalam menyelesaikan latihan, dan kemampuan guru dalam proses pembelajaran semakin baik. Karena sudah memenuhi tolok ukur keberhasilan yaitu nilai rata-rata 70 dan secara klasikal yang mendapat nilai $\geq 70$ minimal $85 \%$, maka penelitian dihentikan. Dengan melihat hasil penilaian di kelas VIII-E di SMP Negeri 1 Situbondo tersebut dapat dijelaskan bahwa faktor-faktor yang paling banyak menyebabkan siswa mengalami kesulitan dalam memahami materi yang ada pada pokok bahasan tersebut adalah:

1) Siswa kurang menentukan luas permukaan dan volume kubus, balok, prisma dan limas.

2) Siswa tidak dapat menyebutkan dan menentukan luas permukaan dan volume kubus, balok, prisma dan limas karena tidak menguasai prasyaratnya.

3) Siswa tidak dapat menjelaskan perbedaan luas permukaan dan volume kubus, balok, prisma dan limas. 
4) Siswa tidak dapat menjelaskan perbedaan tumbuhan dan hewan.

5) Siswa tidak bisa menyebutkan luas permukaan dan volume kubus, balok, prisma dan limas tanpa menghafal. Maka perlua adanya gambaran tentang menentukan luas permukaan dan volume kubus, balok, prisma dan limas dengan lebih mengamati lingkungan sekitar tentang menentukan luas permukaan dan volume kubus, balok, prisma dan limas.

Tindakan yang harus dilakukan pada siswa yang mengalami kesulitan adalah:

1) Siswa yang tidak bisa menentukan luas permukaan dan volume kubus, balok, prisma dan limas, kemudian diberikan PR untuk latihan di rumah.

2) Siswa yang tidak mampu menyebutkan dan menentukan luas permukaan dan volume kubus, balok, prisma dan limas di bimbing guru, kemudian diberikan soal yang lebih sederhana.

3) Siswa yang tidak dapat menjelaskan luas permukaan dan volume kubus, balok, prisma dan limas.

Kriteria keberhasilan siswa dalam mempelajari suatu pokok bahasan adalah:

1) Secara individu bila mereka sudah dapat mencapai nilai $\geq 70$ berarti sudah menyerap materi yang telah diajarkan sebesar $85 \%$ atau lebih dikatakan tuntas belajar.

2) Secara klasikal siswa yang mendapatkan nilai $\geq 70$ mencapai minimal $85 \%$ dari jumlah siswa dalam kelas tersebut.

3) Dengan melihat tabel pengamatan oleh guru lain dalam kegiatan belajar mengajar dapat dijelaskan bahwa dalam siklus I penguasaan guru terhadap materi pelajaran sudah baik, tetapi perhatian guru terhadap siswa kurang merata, sehingga ada beberapa siswa yang pasif yaitu ngantuk dan bermain sendiri, pada siklus II guru dalam kegiatan belajar mengajar ada peningkatan dalam memperhatikan siswa sehingga siswa lebih aktif dan pada siklus II hasil belajar siswa meningkat dan kegiatan guru dalam kegiatan belajar mengajar sudah baik serta perhatiannya sudah merata ke seluruh siswa, sehingga siswa lebih aktif dan antusias dalam mengikuti kegiatan belajar mengajar.

\section{Refleksi}

Hasil observasi terhadap guru pada siklus II yang dilakukan oleh peneliti dalam pembelajaran menunjukkan, hasil guru sebagai Strategi pembelajaran aktif each one teach one dengan media puzzle magnet kekurangan dalam siklus I sudah teratasi berkat 
kerjasama tim peneliti. Guru memberikan semangat, penguatan dan pengakuan atas usaha siswa dalam pembelajaran, baik dalam membimbing siswa sampai memberikan teknik accelerated learning kepada siswa saat mengalami kesulitan menyelesaikan soal. Guru dalam melaksanakan model pembelajaran Strategi pembelajaran aktif each one teach one dengan media puzzle magnet sesuai dengan Rencana Pelaksanaan Pembelajaran berpedoman pada indikator hasil guru mengajar, maka guru dalam menggunakan Strategi pembelajaran aktif each one teach one dengan media puzzle magnet dapat dikategorikan baik.

\section{Analisis Data}

Aktivitas siswa prasiklus belum diterapkan strategi pembelajaran aktif each one teach one dengan media puzzle magnet namun aktivitas siswa menggunakan metode yang lain dengan guru atau peneliti diteliti dengan tujuan ingin mengetahui indikator seperti menjelaskan materi, mempresentasikan dan menarik kesimpulan. Namun setelah diamati oleh guru, siswa dalam pembelajaran tidak aktif yang diamati adalah indikator seperti menjelaskan materi, mempresentasikan dan menarik kesimpulan.

Dengan melihat hasil belajar siswa pada siklus I dari 35 siswa terdapat 11 siswa (31\%) yang tidak tuntas belajar yaitu mendapat nilai kurang dari 70,00, sedang siswa yang tuntas belajar ada 24 siswa (69\%) terhadap materi pembelajaran. Hasil belajar siswa pada siklus II dari 35 siswa terdapat 33 siswa (94\%) yang tidak tuntas belajar yaitu mendapat nilai kurang dari 87,29, sedang siswa yang tuntas belajar ada 2 siswa (6\%) terhadap materi pembelajaran.

\section{Temuan Penelitian}

Berdasarkan pelaksanaan siklus penelitian yang meliputi dua siklus diperoleh beberapa temuan penelitian. Secara umum beberapa analisis yang diperoleh dari hasil penelitian adalah:

1) Pada pelaksanaan siklus I diikuti oleh 35 siswa. Tes terakhir menunjukkan ketuntasan klasikal mencapai 69\%. Dari 35 siswa tersebut ada 24 orang yang masih mendapat nilai dibawah 70. Dalam pelaksanaan tes ada beberapa siswa yang tidak masuk, hal ini juga mempengaruhi ketuntasan belajar.

2) Pada siklus II, tetap diikuti oleh 35 siswa dan hasil pelaksanaan tes diperoleh ada 2 siswa yang belum tuntas belajarnya, sedangkan ketuntasan belajar secara klasikal baik yang ditunjukkan semakin antusiasnya siswa dengan model pembelajaran Strategi pembelajaran aktif each one teach one dengan media puzzle magnet. 
3) Dari hasil observasi pada jawaban tes dan analisis hasil tes pada siklus I, Diketahui bahwa rata-rata kesalahan yang dilakukan siswa, dikarenakan siswa terburu-buru dalam memahami pertanyaan sehingga siswa Melihat teman yang lain sudah selesai mengerjakan soal maka siswa dalam menjawab pertanyaan tersebut terkesan sembarangan. Dengan begitu siswa yang kurang memahami soal dan mengerti soal serta adanya kecerobohan dari siswa sendiri sehingga pekerjaan siswa kurang sempurna.

4) Dari hasil observasi tingkah laku siswa pada siklus I dari hasil observasi tingkah laku siswa pada siklus I, yang mengalami peningkatan dan menunjukkan tingkah laku yang positif yang paling tinggi dalam penerapan model pembelajaran. Hal tersebut didukung oleh teknik siswa sangat antusias sekali dalam belajar kelompok sehingga tutor atau guru (siswa) tidak mengalami kesulitan dalam membimbing siswa agar dapat segera mengerti dan memahami materi tersebut.

5) Dari hasil observasi tingkah laku siswa pada siklus II, yang mengalami peningkatan dan menunjukkan tingkah laku yang positif yang paling tinggi dalam penerapan Strategi pembelajaran aktif each one teach one dengan media puzzle magnet disebabkan oleh si guru benar-benar selektif dalam memilih tutor. Karena tidak bisa sembarangan dalam memilih calon tutor. Guru harus benar-benar tahu karakter siswa yang menjadi tutor serta siswa yang mampu membimbing siswa lain agar siswa dapat benar-benar memahami dan mengerti materi tersebut sehingga tidak ada lagi ketidaktuntasan dalam belajar mengajar.

6) Dari hasil analisis tes pada siklus I diperoleh klasikal sebesar 69\%. Hal ini menunjukkan bahwa penerapan pembelajaran strategi pembelajaran aktif each one teach one dengan media puzzle magnet pada siklus I belum berhasil. Berangkat ketidakberhasilan pada siklus I maka penelitian melanjutkan tindakan perbaikan dengan melaksanakan siklus II. Hasil analisis tes pada siklus II diperoleh ketuntasan klasikal sebesar 94\%. Dengan Keberhasilan siswa pada tes di siklus II, hal ini menunjukkan bahwa pembelajaran dengan pendekatan strategi pembelajaran aktif each one teach one dengan media puzzle magnet telah berhasil dan dapat membawa siswa kepada hasil belajar yang semakin meningkat yang ditunjukkan dengan adanya ketuntasan secara individu dengan nilai rata-rata $\geq 85 \%$ dan secara klasikal $\geq 94 \%$ ketercapaian.

\section{PEMBAHASAN}

Upaya peningkatan hasil belajar siswa yang dilakukan peneliti pada mata pelajaran Matematika pokok bahasan menentukan luas permukaan dan volume kubus, 
balok, prisma dan limas di kelas VIII-E di SMP Negeri 1 Situbondo pada akhirnya berjalan lancar dan berhasil setelah dilaksanakan tindakan pada siklus I dan II, meskipun pada awal pembelajaran suasana kelas masih dalam taraf penyesuaian siswa mengikuti pembelajaran yang peneliti terapkan. Para siswa belum terbiasa belajar dengan teman sebaya karena siswa merasa kaku bila diberi bimbingan oleh teman sebayanya. Dengan adanya kerja keras dan bimbingan yang diberikan guru dan peneliti, hal ini dapat diselesaikan dengan baik. Secara umum guru telah berhasil dalam pengelolaan kelas dengan strategi pembelajaran aktif each one teach one dengan media puzzle magnet..

Pada siklus I dari hasil analisis observasi siswa pada awalnya, menunjukkan hasil yang belum memuaskan disebabkan masih ada beberapa siswa yang belum bisa meninggalkan kebiasaan belajar terpusat pada guru sehingga mereka cenderung pasif. Permasalahan tersebut oleh guru dijadikan patokan untuk memperbaiki sikap siswa pada pertemuan selanjutnya. Hasilnya memang terjadi peningkatan pada aspek keterampilan belajar, namun aspek kemampuan berfikir kreatif siswa masih rendah dibanding aspek yang lain. Siswa kurang memahami soal terutama soal, terburu-buru dalam mengerjakan dan tidak semua siswa kelas VIII-E memiliki buku paket Matematika dan diantara siswa tersebut masih malu dan kurang percaya diri untuk dapat membimbing teman sebaya. Hasil kegiatan pada siklus I ini dapat di garis bawahi bahwa pembelajaran dengan strategi pembelajaran aktif each one teach one dengan media puzzle magnet belum sepenuhnya berjalan dengan baik. Hal ini ditandai dengan belum optimalnya pengembangan aspek tingkah laku siswa.

Pada siklus II, siswa tampak lebih aktif menyampaikan ide dan bertanya tentang materi yang mereka anggap sulit. Siswa, lebih aktif dikarenakan mereka sudah mulai terbiasa belajar dengan mengikuti anjuran peneliti. Siswa semakin antusias setelah guru menginformasikan hasil yang dicapai yang dicapai pada siklus I kurang memuaskan, siswa-siswa tidak canggung lagi dalam belajar kelompok dan memberikan bimbingan serta arahan kepada siswa yang daya serapnya rendah, mereka selalu menunggu contohcontoh soal yang mereka anggap sulit sebagai bahan untuk belajar. Rasa tanggung jawab dalam melaksanakan tugas maupun belajar di kelas mulai tumbuh.

Pada pelaksanaan tes pada siklus I hasil yang dicapai siswa dapat dikatakan belum berhasil. Dalam menjawab soal, rata-rata kesalahan yang dilakukan siswa dikarenakan siswa terburu-buru dalam memahami pertanyaan terutama dalam bentuk soal. Mereka kurang memahami dan mengerti maksud soal sehingga pada siklus II. Pada siklus II, dengan adanya intensitas pemberian latihan soal dan pemberian contoh-contoh soal kesalahan yang dilakukan siswa dalam menjawab soal teratasi. Berdasarkan hasil tes pada siklus I terdapat 11 siswa yang tidak tuntas belajar atau sebesar 69\% yang 
memperoleh nilai < 70. Hal ini menunjukkan bahwa penerapan strategi pembelajaran aktif each one teach one dengan media puzzle magnet belum mencapai tujuan hasil belajar yang diharapkan, yaitu ketuntasan klasikal > 85\%. Ketercapaian secara klasikal di bawah ketentuan yang berlaku, yaitu $69 \%$. Hal tersebut bisa disebabkan kesalahan yang dilakukan siswa dan memang ada 2 siswa yang tidak masuk sekolah serta perlu perbaikan dalam tindakan (guru dan peneliti).

Sedangkan pada siklus II hasil belajar siswa yang memperoleh nilai $>70$ dan sebanyak 33 siswa atau sebesar 94\% yang memperoleh nilai $>85 \%$. Sebagian besar siswa telah memahami yang berhubungan dengan pemahaman konsep pada materi Menentukan luas permukaan dan volume kubus, balok, prisma dan limas dengan baik, yang ditunjukkan dengan penurunan ketidaktuntasan siswa secara perseorangan dan peningkatan hasil belajar secara klasikal lebih dari 69\% yaitu mencapai 94\%.

Berdasarkan pembahasan tersebut dapat disimpulkan bahwa hasil kegiatan penerapan strategi pembelajaran aktif each one teach one dengan media puzzle magnet pada siklus II menjadi lebih baik dan pembelajaran pada siklus I maupun sebelum tindakan siklus. Penerapan strategi pembelajaran aktif each one teach one dengan media puzzle magnet telah berhasil meningkatkan hasil belajar siswa yang maksimal.

\section{KESIMPULAN}

Berdasarkan hasil penelitian dan pembahasan yang telah dilakukan, maka dapat disimpulkan bahwa penerapan strategi pembelajaran aktif each one teach one dengan media puzzle magnet dapat meningkatkan hasil belajar dari 69\% siklus I menjadi $94 \%$ siklus II mata pelajaran matematika materi pokok bangun ruang sisi datar di kelas VIII-E di SMP Negeri 1 Situbondo tahun pelajaran 2018/2019

\section{DAFTAR PUSTAKA}

Arikunto Suharsimi, 2015. Dasar-dasar Evaluasi Pendidikan. Jakarta: Bumi Aksara.

Arikunto, S. 2006. Metode Penelitian Kualitatif. Jakarta: Bumi Aksara.

Arsyad, Azhar. 2013. Media Pembelajaran. Jakarta: Rajawali Pers

Dimyati dan Mudjiono, 2006. Belajar dan Pembelajaran, Jakarta : Penerbit Rineka Cipta

Hobri 2006. Penelitian Tindakan Kelas (PTK). Jember : UPTD Balai Pengembangan Pendidikan (BPP).

Maleong, 2012. Metodologi Penelitian Kualitatif, Bandung: Remaja Rosda karya

Sanjaya, 2008. Strategi Pembelajaran Beroroentasi Standar Proses Pendidikan. Jakarta:

Kencana Prenada Media Group 
Sanjaya, 2007. Strategi Pembelajaran Beroroentasi Standar Proses Pendidikan. Jakarta: Kencana Prenada Media Group

Silberman, 2007. Pembelajaran Aktif 101 Strategi untuk Mengajar Secara Aktif. Jakarta: Indeks

Slameto. 2013. Belajar dan Faktor yang mempengaruhinya. Jakarta: Rineka. Cipta

Sudjana, 2000. Penilaian Hasil Proses Belajar Mengajar. Bandung: Remana Rosdakarya Sugihartono, 2007. Psikologi Pendidikan. Yogyakarta: UNY Press.

Surya, Moh. 2014. Strategi Kognitif. Garut: STKIP Garut Press

Sutarman, 2015. Pengantar Teknologi Informasi. Jakarta: PT. Bumi Aksara

Tilaar, 2010. Analisis Kebijakan Pendidikan Suatu. Bangsa. Bandung: Remaja Rosdakarya

Warsono dan Hariyanto, 2012. Pembelajaran Aktif (Teori dan Asesmen). Bandung: Remaja Rosdakarya.

Zaini, 2008. Strategi Pembelajaran Aktif, Yogyakarta: CTSD, Edisi Revisi 